\title{
Wheat Yield Response to Water Deficit under Central Pivot Irrigation System Using Remote Sensing Techniques
}

\author{
M. A. El-Shirbeny*, A. M. Ali, A. Rashash, M. A. Badr \\ National Authority for Remote Sensing and Space Sciences (NARSS), Cairo, Egypt \\ Email: "mshirbeny@yahoo.com, m.elshirbeny@narss.sci.eg
}

Received 12 May 2015; accepted 22 August 2015; published 25 August 2015

\begin{abstract}
Scarcity of rainfall and limited irrigation water resources is the main challenge for agricultural expanding policies and strategies. At the same time, there is a high concern to increase the area of wheat cultivation in order to meet the increasing local consumption. The big challenge is to incerese wheat production using same or less amount of irrigation water. In this trend, the study was carried out to analyze the sensitivity of wheat yield to water deficit using remotely sensed data in El-Salhia agricultural project which located in the eastern part of Nile delta. Normalized Difference Vegetation Index (NDVI) and Land Surface Temperature (LST) were extracted from Landsat 7. Water Deficit Index (WDI) used both LST minus air temperature (Tair) and vegetation index to estimate the relative water status. Yield response factor (ky) was derived from relationship between relative yield decrease and relative evapotranspiration deficit. The relative Evapotranspiration deficit was replaced by WDI. Linear regression was found between predicted wheat yield and actual wheat yield with $0.2^{-6}, 0.025,0.252$ and 0.76 as correlation coefficient on $30^{\text {th }}$ of Dec. 2012, $15^{\text {th }}$ of Jan. 2013, $16^{\text {th }}$ of Feb. 2013 and $20^{\text {th }}$ of Mar. 2013 respectively. The main objective of this study is using a combination between FAO 33 paper approach and remote sensing techniques to estimate wheat yield response to water.
\end{abstract}

\section{Keywords}

Normalized Difference Vegetation Index (NDVI), Land Surface Temperature (LST), Water Deficit Index (WDI), Yield Response Factor (ky), Arid Region and Egypt

\section{Introduction}

About 21\% of the world's food depends on the wheat crop, which grows on 200 million hectares of farmland worldwide. Most of developing countries including Egypt are wheat importers. About 81\% of wheat in the developing world is produced and utilized within the same country, if not the same community [1]. With a rapidly growing world population, the pressure on limited fresh water resources increases. Egypt consumes 14 million

*Corresponding author.

How to cite this paper: El-Shirbeny, M.A., Ali, A.M., Rashash, A. and Badr, M.A. (2015) Wheat Yield Response to Water Deficit under Central Pivot Irrigation System Using Remote Sensing Techniques. World Journal of Engineering and Technology, 3, 65-72. http://dx.doi.org/10.4236/wjet.2015.33B011 
ton of wheat yearly, on the other hand, it produces about 8 million ton yearly. Although, wheat is low water consumption crop compared with other crops in Egypt, it is sensitive to water stress in some phonological stages.

Agriculture is the largest water consuming sector. It faces competing demands from other sectors, such as the industrial and the domestic sectors. With an increasing population and less water available for agricultural production, the food security for future generations is at stake. The great challenge of the agricultural sector is to produce more food from less water, which can be achieved by increasing Crop Water Productivity (CWP) [2]. Agronomical research and improving land and water management practices succeeded to increase CWP significantly during the years. Limited water is the principal factor responsible for reduced cereal yields globally and especially in Mediterranean environment [3]. Crop productivity is determined by the total amount of precipitation and also by its distribution during the growing season [4] [5].

Yield is defined as the marketable part of the total above ground biomass production; for wheat, maize and rice total grain yield is considered, and for cotton the total lint yield and total seed yield. Unfortunately, very few sources give the moisture content at which the yield is measured, which inevitably means an error that exists in the final results [2]. Grain yield depends on number of plants per unit land area, spikes per plant, spikelets per spike, grains per spikelet, and single grain weight (SGW). These yield determining components are interrelated and increase a crop's capacity to compensate for losses in any of the components caused by temporary, unfavorable conditions [6]. The response of yield to water supply is quantified by [7] through the yield response factor $(\mathrm{ky})$ which relates relative yield decrease $(1-\mathrm{Ya} / \mathrm{Ym})$ to relative evapotranspiration deficit (1-ETa/PET). Water deficit of a given magnitude was expressed in the ratio actual evapotranspiration (ETa) and potential evapotranspiration (PET) may either occur continuously over the total growing period of the crop or it may occur during any of the individual growth periods (i.e. establishment (0), vegetative (1), flowering (2), yield formation (3), or ripening (4) period ). Determination of PET that is substantially different from ETa has been made on the basis of a so-called two-step approach. ETo is first estimated and semi-empirical coefficient (crop coefficient, Kc) is then applied to take into account all other crop and environmental factors [8]-[11]. Similarities between Kc curve and a satellite-derived vegetation index showed potential for modeling a Kc as a function of the vegetation index [11]. Therefore, the possibility of directly estimating Kc from satellite data was investigated [9] [12]-[15].

Crop development and growth are subject to drought stress at different stages of the growth cycle, which results in differences in composition of yield components. This interrelationship was also evident when the role of grain number and weight was compared in yield determination in winter and spring wheat (Triticum aestivum L.) [16]. Generally, water deficit during the rapid spike-growth phase from booting to anthesis reduces floret set due to decreased shoot water status and increased accumulation of abscisic acid [17]. Number of grain bearing tillers and grain set may be also reduced [18] [19]. WDI is a function of actual evapotranspiration (ETa) to potential evapotranspiration (PET) ratio [20]:

$$
\mathrm{WDI}=1-\mathrm{ETa} / \mathrm{PET}
$$

where: ET (mm/day) is the product of an uptake coefficient $(\alpha, \mathrm{mm} /$ day) and available water $(\theta-\theta \mathrm{WP})$ when ET is less than PET (mm/day) [21]: If ET $<$ PET, ET $=\alpha(\theta-\theta \mathrm{WP})$ and If ET $\geq$ PET, ET $=$ PET. PET occurs when the availability of soil water does not limit transpiration. It is estimated using the FAO 56 Penman-Monteith model [8]. [22] developed the WDI that used both surface minus air temperature and a vegetation index to estimate the relative water status of a field. The crop begins to experience some level of stress when the WDI falls to the right of a line formed between points 1 and 4 [23].

Productivity response to water stress is different for each crop and this response is expected to vary with the climate. Therefore, the critical values of WDI should be determined for a particular crop in different climates and soils to use it in yield prediction and irrigation scheduling. Many satellite data were used to calculate WDI. [24] used NOAA/AVHRR to calculate WDI in eastern part of Nile delta-Egypt. The main objective of this work is studying wheat yield response to water deficit under central pivot irrigation system using remote sensing techniques.

\section{Materials and Methods}

\subsection{Study Area Location}

El-Salhia project is located at the eastern part from Nile Delta. It is bounded by 30²2'35" and 30³1'19" lati- 
tudes and $31^{\circ} 55^{\prime} 24^{\prime \prime}$ and $32^{\circ} 02^{\prime} 38^{\prime \prime}$ longitudes as shown in (Figure 1). The whole area of the project is about 13,800 ha. Two irrigation systems are used in the project; the central pivots and the drip irrigation. The project has about 100 pivots irrigation units. Each pivot unit irrigates an area of about 63.6 ha when pivot length is 450 meter. The farms that are cultivated by orchards are irrigated by drip irrigation system. Climate in the study area is Dry Arid according to Köppen Climate Classification System, where precipitation is less than $50 \%$ of potential evapotranspiration. Annual average temperature is over $18^{\circ} \mathrm{C}$. The average rainfall is approximately 20 $\mathrm{mm} /$ year. The maximum values of rainfalls are registered in January with average of $6.9 \mathrm{~mm}$. The average maximum temperatures reach $\left(34.6^{\circ} \mathrm{C}\right)$ in June and January represents the coldest month $\left(19.0^{\circ} \mathrm{C}\right)$. The minimum temperatures range between $8.0^{\circ} \mathrm{C}$ in January to $21.5^{\circ} \mathrm{C}$ in August.

\subsection{Remote Sensing Data}

Remote sensing provides spatial coverage by measurement of reflected and emitted electromagnetic radiations, across a wide range of wavebands, from the earth's surface and surrounding atmosphere. Landsat ETM+ imageries, (path 176/row 039) around 10 a.m. local time with 30 meter ground resolution, on $30^{\text {th }}$ of Dec. 2012, $15^{\text {th }}$ of Jan. 2013, $16^{\text {th }}$ of Feb. 2013 and $20^{\text {th }}$ of Mar. 2013 were used in the current study to estimate LST, NDVI and WDI.

\subsection{Land Surface Temperature (LST)}

For landsat ETM+ data, the recorded digital numbers (DN) were converted to radiance units (Rad) using the calibration coefficients specific for each band.

$$
\text { Radiance }=\text { Gain* DN }+ \text { offset }
$$

Surface emissivity $\left(E_{0}\right)$ was estimated from the NDVI using the empirical equation developed from raw data on NDVI and thermal emissivity [25].

$$
\mathrm{E}_{\mathrm{o}}=0.9932+0.0194 \ln \mathrm{NDVI}
$$

The radiant temperature $\left(\mathrm{T}_{\mathrm{o}}\right)$ can be calculated from band 6 radiance (Rad6) using calibration constants $\mathrm{K} 1=$ 666.09 and $\mathrm{K} 2=1282.71[26]$.

$$
\mathrm{T}_{\mathrm{o}}=\mathrm{K} 2 / \ln ((\mathrm{K} 1 / \mathrm{Rad} 6)+1)
$$

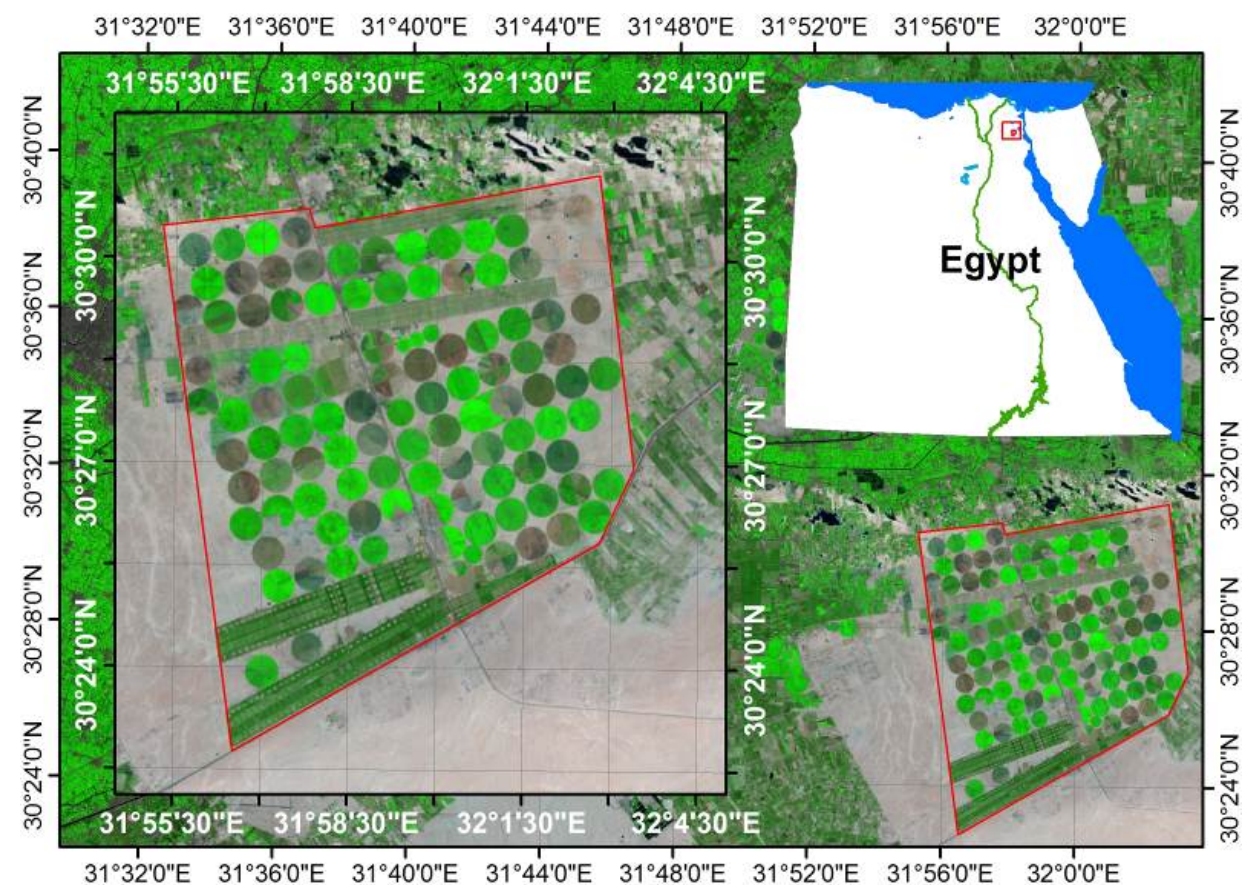

Figure 1. Location map of the study area. 
The resulting temperature (Kelvin) is satellite radiant temperature of the viewed Earth atmosphere system, which is correlated with, but not the same as, the surface (kinetic) temperature. The atmospheric effects and surface thermal emissivity have to be considered in order to obtain the accurate estimate of surface temperature from satellite thermal data [27]. The surface temperature is calculated from the top of atmosphere radiant temperature $\left(\mathrm{T}_{0}\right)$ and estimated surface emissivity $\left(\mathrm{E}_{0}\right)$ as:

$$
\mathrm{T}=\mathrm{T}_{\mathrm{o}} / \mathrm{E}_{\mathrm{o}}
$$

\subsection{Water Deficit Index (WDI)}

[22] developed the WDI (Equation (6)) that uses both surface minus air temperature and a vegetation index to estimate the relative water status of a field (Figure 2).

$$
\text { WDI }=\left(\mathrm{dT}-\mathrm{dTL}_{13}\right) /\left(\mathrm{dTL}_{24}-\mathrm{dTL}_{13}\right)
$$

where: $\mathrm{dT}$ is the measure of surface subtracting air temperature at a particular percent cover, dTL $\mathrm{d}_{13}$ is the surface minus air temperature determined by the line from points 1 to 3 for the percent cover of interest ("wet” line), and $\mathrm{dTL}_{24}$ is the temperature difference on the line formed between points 2 and 4 (“dry” line). Graphically, WDI can be viewed as the ratio of the distances $\mathrm{AB}$ to $\mathrm{AC}$ in the previous figure. As the WDI considers evaporation from a soil surface as well as the crop, it can be interpreted as a measure of the amount of ETa occurring relative to PET (Equation (1)). While WDI could be used to estimate ET, it does not provide a direct measure of crop water stress. As an index, it is vary according to soil-water evaporation as well as crop transpiration. The crop begins to experience levels of stress when the WDI falls to the right of a line formed between points 1 and 4 [23].

\subsection{Yield Response to Water}

The major importance in production planning is the yield response to water deficit. The response of yield to water supply is quantified through the yield response factor (ky) which relates relative yield decrease to relative evapotranspiration deficit. Water deficit of a given magnitude, is expressed in the ratio ETa and PET, may either occur continuously over the total growing period of the crop or it may occur during any one of the individual growth periods. The yield response to water deficit in different individual growth periods has a major importance in the scheduling of limited supply in order to obtain highest yield. Generally, crops are more sensitive to water deficit during emergence, flowering and early yield formation than early (vegetative, after establishment) and late growth periods (ripening) [7]. For Wheat, spring wheat is more sensitive than winter wheat and flowering period is more sensitive than yield formation and yield formation is more sensitive than vegetative period. In order to quantify the effect of water stress, it is necessary to derive the relationship between relative yield decrease and relative evapotranspiration deficit given by the empirically derived yield response factor (ky) [7].

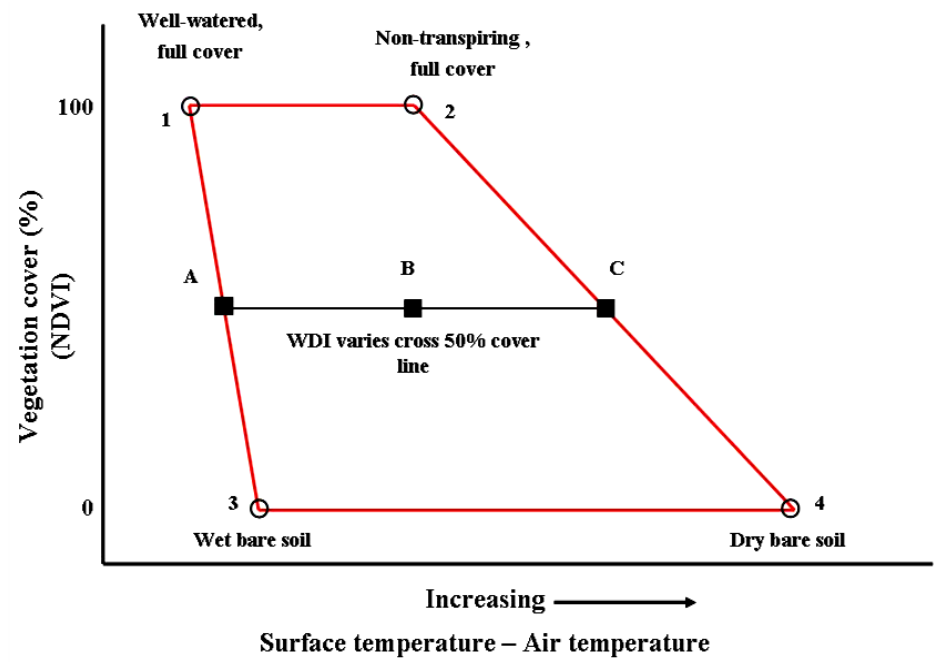

Figure 2. Water Deficit Index (WDI) trapezoid. 


$$
(1-\mathrm{Ya} / \mathrm{Ym})=\mathrm{ky}(1-\mathrm{ETa} / \mathrm{PET})
$$

where: Ya is actual harvested yield; Ym is maximum harvested yield; Ky is yield response factor; ETa is actual evapotranspiration; PET is potential evapotranspiration. Relative Evapotranspiration deficit could be replaced by WDI. From equation (1 and 7) remote sensing can take a place in FAO 33 equation as follows.

$$
\left(1-\mathrm{Y}_{\mathrm{a}} / \mathrm{Y}_{\mathrm{m}}\right)=\mathrm{Ky}(\mathrm{WDI})
$$

Figure 3 is a flowchart that shows the whole process to derive yield response from remote sensing data.

\section{Results and Discussion}

\subsection{Water Deficit Index (WDI)}

WDI is a function of ETa to PET ratio [28]. WDI of 0 indicates no water stress, and a value of 1 represents maximum water stress (Figure 4). Water stress causes stomatal closure and interruption in energy dissipation which results in rise of leaf temperature. The leaf or canopy temperature is used as an indicator of plant water stress [29].

WDI has been developed for the reference crop as a generic index for quantifying crop water stress for various crops. It explores how reliable of water stress estimations would be for various crops. WDI represents the suffering of crop from water shortage or/and thermal stress. WDI in the study area varied from stage to another and from year to year. It is affected by applied irrigation system, soil type and climatic conditions.

The minimum values of WDI for wheat in study area were $0.08,0.03,0.03$, and 0.02 and maximum values were $0.51,0.27,0.2$, and 0.14 on $30^{\text {th }}$ of Dec. 2012, $15^{\text {th }}$ of Jan. 2013, $16^{\text {th }}$ of Feb. 2013 and $20^{\text {th }}$ of Mar. 2013 respectively. The values of WDI were high in the first stage because the canopy was not $100 \%$ coverage and the temperature of soil was higher than temperature of canopy.

\subsection{Yield Prediction}

Actual wheat yield can only be determined by accurately measuring the area and determining the weight of grain harvested. Environmental stress always reduces Ym. In (Figure 5) the predicted Wheat yield was plotted against actual yield, the relations were varied during different phenological stages where $\mathrm{R}^{2}$ were $0.2^{-6}, 0.03,0.3$ and 0.76. The yield response factor (ky) for most crops is derived through the assumption that the relationship between relative yield $(\mathrm{Ya} / \mathrm{Ym})$ and relative evapotranspiration $(\mathrm{ETa} / \mathrm{ETm})$ is linear and is valid for water deficits of up to about 50 percent or $(1-\mathrm{ETa} / \mathrm{ETm}=0.5)$. The values of ky are based on an analysis of experimental field data covering a wide range of growing conditions. The experimental results used represent high-producing

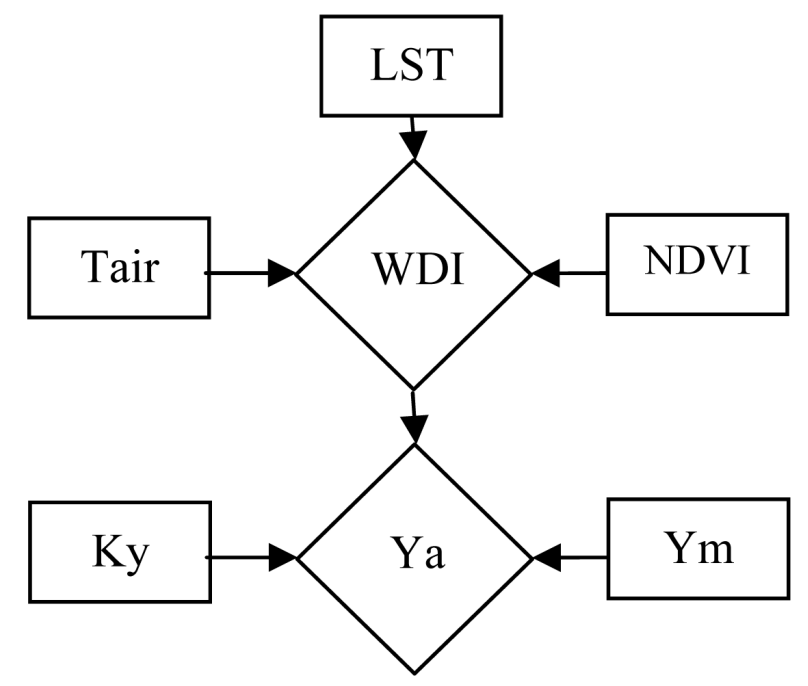

Figure 3. Illustrates the combination of FAO 33 paper approach and remote sensing techniques to estimate yield response to water. 

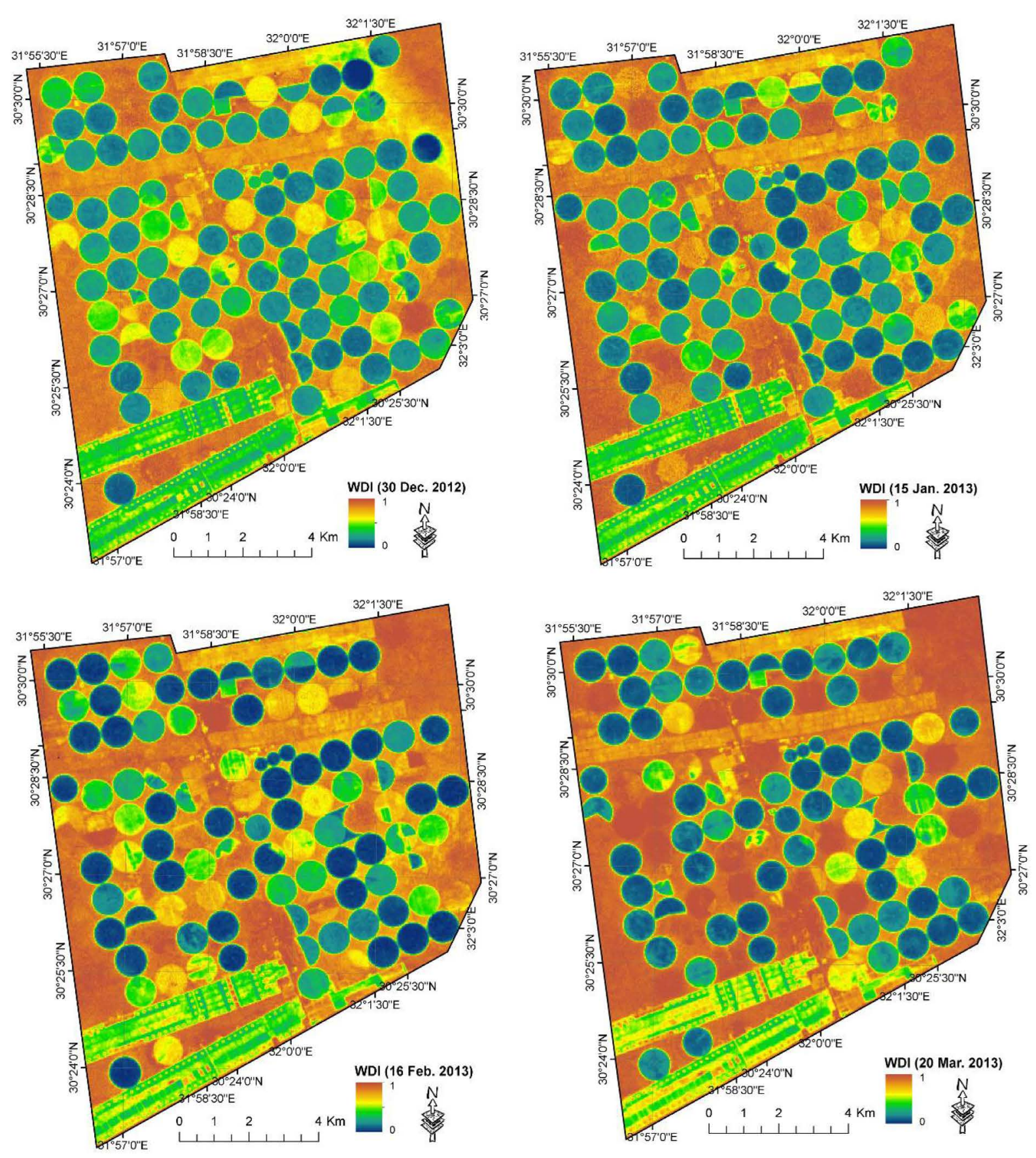

Figure 4. WDI calculated from remotely sensed data for study area.

crop varieties, well-adapted to the growing environment and grown under a high level of crop management [7]. In the current work, yield response factor (ky) values of FAO 33 paper for wheat were used to predict the wheat yield through remotely sensed data.

\section{Conclusion}

The values of WDI were higher in establishment and vegetative stages than flowering and yield formation because the soil was not fully covered with canopy and the temperature of soil was higher than temperature of canopy. This factor reduces the accuracy of this method in partial canopy coverage case. The predicted wheat 

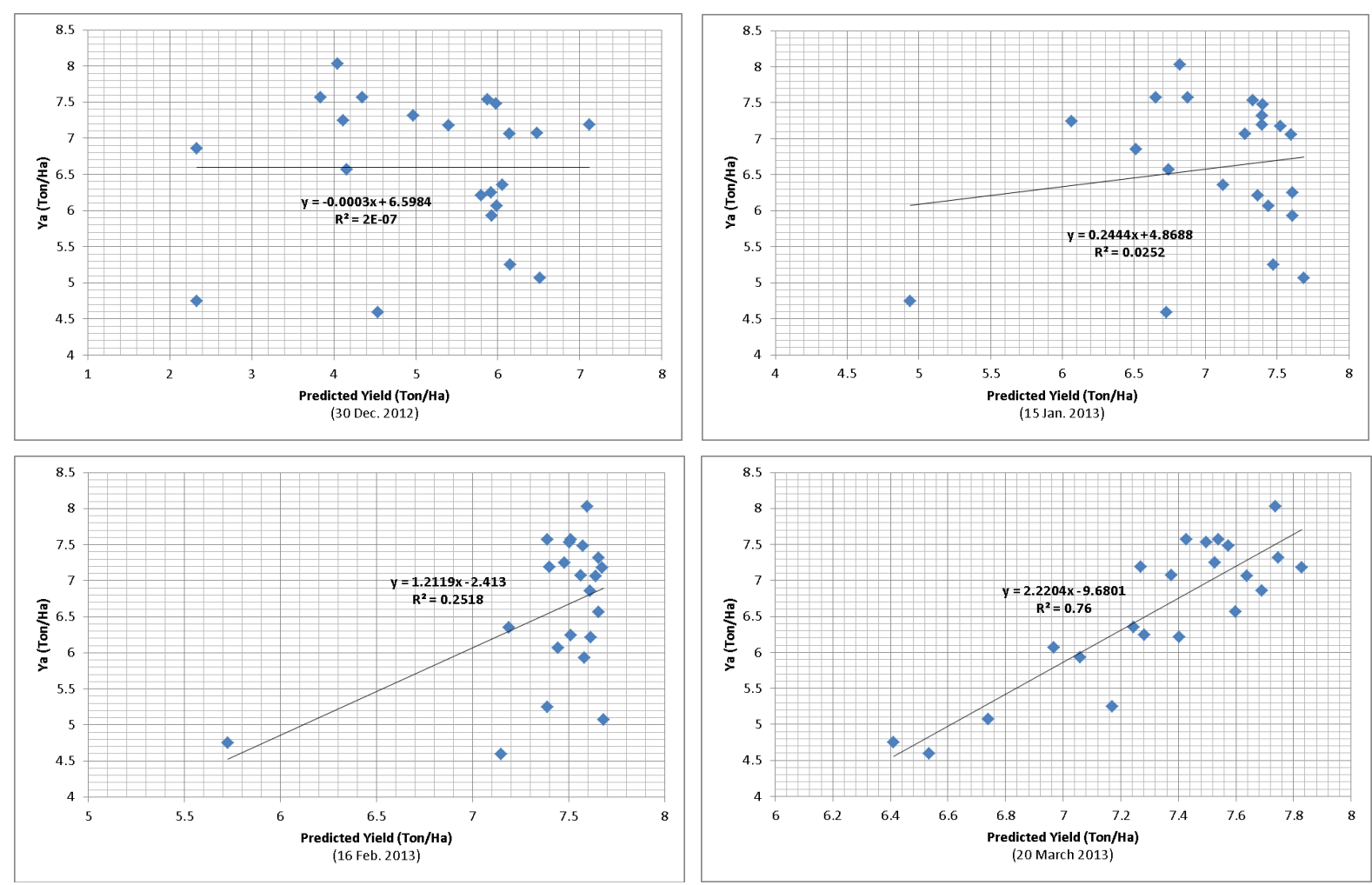

Figure 5. shows the relation between predicted wheat yield (calculated according to Equation (8)) and actual wheat yield.

yield was plotted against actual yield, the relations were varied during different phenological stages where $\mathrm{R}^{2}=$ $0.2^{-6}, 0.03,0.3$ and 0.76 . There was no correlation in establishment and vegetative stages but it improved in flowering stage and it was good in yield formation stage. The combination of FAO 33 paper approach and remote sensing techniques is a good idea to estimate yield response to water but it needs to improve.

\section{References}

[1] http://www.fao.org

[2] Zwart, S.J. and Bastiaanssen, W.G.M. (2004) Review of Measured Crop Water Productivity Values for Irrigated Wheat, Rice, Cotton and Maize. Agricultural Water Management, 69, 115-133. http://dx.doi.org/10.1016/j.agwat.2004.04.007

[3] Acevedo, E.H., Silva, P.C., Silva, H.R. and Solar, B.R. (1999) Wheat Production in Mediterranean Environments. In: Satorre, E.H. and Slafer, G.A., Eds., Wheat Ecology and Physiology of Yield Determination, Food Products Press, New York, 295-323.

[4] Loss, S.P. and Siddique, K.H.M. (1994) Morphological and Physiological Traits Associated with Wheat Yield Increases in Mediterranean Environments. Advances in Agronomy, 52, 229-276. http://dx.doi.org/10.1016/S0065-2113(08)60625-2

[5] Slafer, G.A. (2003) Genetic Basis of Yield as Viewed from a Crop Physiologist's Perspective. Annals of Applied Biology, 142, 117-128. http://dx.doi.org/10.1111/j.1744-7348.2003.tb00237.x

[6] Royo, C., Villegas, D., Rharrabti, Y., Blanco, R., Martos, V. and Garcia del Moral, L.F. (2006) Grain Growth and Yield Formation of Durum Wheat Grown at Contrasting Latitudes and Water Regimes in a Mediterranean Environment. Cereal Research Communications, 34, 1021-1028. http://dx.doi.org/10.1556/CRC.34.2006.2-3.233

[7] Doorenbos, J. and Kassam, O.W. (1979) Yield Response to Water. FAO Irrigation And Drainage, Paper No. 33, FAO, Rome.

[8] Allen, R.G., Perrier, L.S., Raes, D. and Smith, M. (1998) Crop Evapotranspiration: Guidelines for Computing Crop Requirements,. FAO Irrigation and Drainage, Paper No. 56, Rome.

[9] Magliulo, V., d'Andria, R. and Rana, G. (2003) Use of the Modified Atmometer to Estimate Reference Evapotranspiration in Mediterranean Environments. Agricultural Water Management, 63, 1-14. 
http://dx.doi.org/10.1016/S0378-3774(03)00098-2

[10] da Silva, V.de.P.R., Borges, C.J.R, Farias, C.H.A., Singh, V.P., Albuquerque, W.G. and da Silva, B.B. (2012) Water Requirements and Single and Dual Crop Coefficients of Sugarcane Grown in a Tropical Region, Brazil. Agricultural Sciences, 3, 274-286. http://dx.doi.org/10.4236/as.2012.32032

[11] Kamble, B., Kilic, A. and Hubbard, K. (2013) Estimating Crop Coefficients Using Remote Sensing-Based Vegetation Index. Remote Sensing, 5, 1588-1602. http://dx.doi.org/10.3390/rs5041588

[12] El-Shirbeny, M.A., Ali, A. and Saleh, N. (2014) Crop Water Requirements in Egypt Using Remote Sensing Techniques. Journal of Agricultural Chemistry and Environment, 3, 57-65. http://dx.doi.org/10.4236/jacen.2014.32B010

[13] El-Shirbeny, M.A., Ali, A.M., Badr, M.A. and Bauomy, E.M. (2014) Assessment of Wheat Crop Coefficient Using Remote Sensing Techniques. World Research Journal of Agricultural Sciences, 1, 12-17.

[14] El-Shirbeny, M.A., Saleh, N.H. and Ali, A.M. (2014) Estimation of Potential Crop Evapotranspiration Using Remote Sensing Techniques. Proceedings of the 10th International Conference of AARSE, 460-468.

[15] El-Shirbeny, M.A., Alsersy, M.A.M., Saleh, N.H. and Abu-Taleb, K.A. (2015) Changes in Irrigation Water Consumption in the Nile Delta of Egypt Assessed by Remote Sensing. Arabian Journal of Geosciences (in Press). http://dx.doi.org/10.1007/s12517-015-2005-2

[16] Peltonen-Sainio, P., Kangas, A., Salo, Y. and Jauhiainen, L. (2007) Grain Number Dominates Grain Weight in Temperate Cereal Yield Determination: Evidence Based on 30 Years of Multi-Location Trials. Field Crops Research, 100, 179-188. http://dx.doi.org/10.1016/j.fcr.2006.07.002

[17] Westgate, M.E., Passioura, J.B. and Munns, R. (1996) Water Status and ABA Content of Floral Organs in DroughtStressed Wheat. Australian Journal of Plant Physiology, 23, 763-772. http://dx.doi.org/10.1071/PP9960763

[18] Foulkes, M.J., Sylvester-Bradley, R., Weightman, R. and Snape, J.W. (2007) Identifying Physiological Traits Associated with Improved Drought Resistance in Winter Wheat. Field Crops Research, 103, 11-24. http://dx.doi.org/10.1016/j.fcr.2007.04.007

[19] Rajala, A., Hakala, K., Makela, P., Muurinen, S. and Peltonen-Sainio, P. (2009) Spring Wheat Response to Timing of Water Deficit through Sink and Grain Filling Capacity. Field Crops Research, 114, 263-271. http://dx.doi.org/10.1016/j.fcr.2009.08.007

[20] Hiler, E.A. and Clark, R.N. (1971) Stress Day Index to Characterize Effects of Water Stress on Crop Yields. Transactions of Hydrology (210-VI-NEH).

[21] Dardanelli, J.L., Ritchie, J.T., Calmon, M., Andrianiand, J.M. and Collino, D.J. (2004) An Empirical Model for Root Water Uptake. Field Crops Research, 87, 59-71. http://dx.doi.org/10.1016/j.fcr.2003.09.008

[22] Moran, M.S., Clarke, T.R., Inoue, Y. and Vidal, A. (1994) Estimating Crop Water Deficit Using the Relation between Surface Air Temperature and Spectral Vegetation Index. Remote Sensing of Environment, 49, 246-263. http://dx.doi.org/10.1016/0034-4257(94)90020-5

[23] Clarke, T.R. (1997) An Empirical Approach for Detecting Crop Water Stress Using Multi-Spectral Airborne Sensors. Horticulture Technology, 7, 9-16.

[24] El-Shirbeny, M.A., Aboelghar, M.A., Arafat, S.M. and El-Gindy, A.G.M. ( 2014) Assessment of the Mutual Impact between Climate and Vegetation Cover Using NOAA-AVHRR and Landsat Data in Egypt. Arabian Journal of Geosciences, 7, 1287-1296. http://dx.doi.org/10.1007/s12517-012-0791-3

[25] Valor, E. and Caselles, V. (1996) Mapping Land Surface Emissivity from NDVI: Application to European, African and South American Areas. Remote Sensing of Environment, 57, 167-184. http://dx.doi.org/10.1016/0034-4257(96)00039-9

[26] Goetez, S.J., Halthore, R.N., Hall, F.G. and Markham, B.L. (1995) Surface Temperature Retrieval in Temperate Grassland with Multi-Resolution Sensors. Journal of Geophysical Research, 100, 397-410.

[27] Norman, J.M., Divakarla, M. and Goel, N.S. (1995) Algorithms for Extracting Information from Remote Thermal-IR Observations of the Earth's Surface. Remote Sensing of Environment, 51, 157-168. http://dx.doi.org/10.1016/0034-4257(94)00072-U

[28] Hiler, E.A. and Clark, R.N. (1971) Stress Day Index to Characterize Effects of Water Stress on Crop Yields. Transactions of Hydrology (210-VI-NEH).

[29] Jackson, R.D., Idso, S.B., Reginato, R.J. and Pinter, P.J. (1981) Canopy Temperature as a Crop Water Stress Indicator, Water Resource Research, 17, 1133-1138. http://dx.doi.org/10.1029/WR017i004p01133 